\title{
PROFITABILITY AND RESOURCE USE EFFICIENCY OF POTATO CULTIVATION IN MUNSHIGANJ DISTRICT OF BANGLADESH
}

\author{
H.K. Sujan ${ }^{1 *}$, F. Islam ${ }^{1}$, M.H. Kazal ${ }^{2}$ and R.K. Mondal ${ }^{3}$ \\ ${ }^{1}$ Faculty of Agribusiness Management, Sher-e-Bangla Agricultural University, Dhaka 1207, Bangladesh \\ ${ }^{2}$ Department of Development and Poverty Studies, Sher-e-Bangla Agricultural University \\ Dhaka 1207, Bangladesh \\ ${ }^{3}$ Department of Agricultural Economics, Sher-e-Bangla Agricultural University \\ Dhaka 1207, Bangladesh
}

\begin{abstract}
Potato is the third largest food crop in Bangladesh by tonnage of production. Its acreage and production are also increasing in day after day. This study was accomplished to examine the profitability and resource use efficiency of potato cultivation in five upazilas of Munshiganj district of Bangladesh. A total of 52 farmers were selected randomly from the study area. Data were collected through farm survey by using a suitable pre-tested questionnaire in February-March, 2016. Profitability analysis, Cobb-Douglas production function, MVP, MFC and Farm Budgeting model were used to analyze the objectives. Average gross return, gross margin and net return were found Tk. 3,47,200, Tk. $1,47,125$ and Tk. 1,17,300, respectively. Benefit-cost ratio was found 1.51 and 1.74 on full cost and variable cost basis, respectively. The key production factors, i.e. human labour, land preparation, seed, fertilizer, insecticides and irrigations had significant effect on gross return of potato. Resource use efficiency analysis revealed that farmers were not efficient in using resources in potato cultivation. Human labor, land preparation, insecticide and irrigation were under-utilized and therefore increasing use of those resources could maximize the profitability. Seed and fertilizer constituted major parts of the cost of production hence optimum use of those resources could also enhance the profitability and resource use efficiency of potato cultivation in Munshiganj district.
\end{abstract}

Keywords: Potato, profitability, resource use efficiency.

\section{INTRODUCTION}

Potato is an important and leading staple crop of the world and occupied topmost position after rice and wheat in respect of production consumption (Akhter et al.,

\footnotetext{
* Corresponding author e-mail: mhksujan@ gmail.com
} 
1998). Bangladesh experienced much progress in its potato production in the past decades as it has increased by 5 percent per annum (Islam et al., 2000). The country has ranked seventh position in the world in terms of potato production in 2015 (FAO, 2015). In 2014-15, around 92,54,000 metric tons of potato have been produced from $4,71,000$ hectares $(3.09 \%$ of total cultivated area) of land in Bangladesh (BBS, 2015). Among all crops, potato (Solanum tuberosum L.) is one of the most important vegetables as well as cash crops in Bangladesh (Haque et al., 2012). In fact, short cycle of potato frees the land for cultivating other crops (Walker et al., 1999). Per unit of land and time potato was more productive than any other food crops (Azimuddin et al., 2009). The annual growth rates of area, production and yield of potato were estimated at $7.14 \%, 9.90 \%$ and $2.76 \%$ during $1989-90$ to $2008-09$, respectively (Miah et al., 2011). Potato production is highly profitable and it could provide cash money to farmer. In terms of profitability, potato production was more attractive than any other winter vegetables. Per unit yield and gross return of potato were found higher than other competitive crops (Akhter et al., 2001). The farmers who used quality seed obtained higher yield and profit. But scarcity of quality seed compelled some farmers to use the inferior seed (Huq, 1998). As a result, the Tuber Crop Research Centre (TCRC) of BARI released 40 HYV potato varieties which have good yield potential and tolerant to insect pests and diseases (Haque et al., 2012). BADC also produces quality potato seeds under contract farming and distribute them to the producers, yet evidence is lacking (Moniruzzaman et al., 2015). Diamant, Cardinal and Granola are the most popular varieties among all the released varieties of BARI and are largely grown in Munshiganj, Rangpur and Bogra district respectively (Khalil et al., 2013). These varieties have been distributed to the farmers through different GOs, NGOs and private firms. Potato, a high biomass yielder, utilizes huge quantities of nutrient particularly nitrogen, phosphorus and potassium (Elias et al., 1992). Efficiency and input use pattern varies with the socio-economic characteristics of farmer or manager (Islam et al., 2016). Technical and managerial skills on cultivation practices and provision of technical knowledge to control diseases as well as proper allocation of inputs and available resources would help to increase profitability and productivity of potato (Bajracharya and Sapkota, 2017). Several studies in other countries have shown that there is significant potential for raising agricultural output or profitability by improving productive (technical and allocative) efficiency using existing resources (Rahman, 2002). Yadav et al. (2015) worked on productivity, profitability and resource use efficiency of potato in India and found that potato based various cropping sequence differ significantly for most of the desirable parameters which influence the utilization of natural resources. Bajracharya and Sapkota (2017) conducted a research on profitability and productivity of potato (Solanum tuberosum) in Baglung district of Nepal and found the average productivity was 9.89 ton per hectare with per hectare total cost and total income of NRs. (Nepali rupees) 1,97,186 and NRs. 2,68,047, respectively. Islam et al. (2000) carried out a research on the title "Potato production system in Bangladesh: 
Resource use, productivity, efficiency and comparative profitability of true potato seed technology over traditional tuber technology" and found from efficiency analysis that the potato growers using TPS technology allocated their resources in rational stage of production. Agricultural production policy decisions in Bangladesh are constrained by lack of information on profitability of growing different agricultural crops (Sarkar et al., 2014). Some economic investigations on potato cultivation in Bangladesh were undertaken by different agencies but which were not adequate. Nevertheless, sufficient number of research work were not undertaken for analyzing the profitability and resource use efficiency of potato production in a major potato producing area like Munshiganj district. So, the specific objective of the present study is to analyze the profitability, resource use efficiency and the factors affecting the production of potato in the selected study area.

\section{MATERIALS AND METHODS}

A micro-level study based on primary cross-section data was designed to attain the objectives of this study. The methodology of the study is mainly about the sampling procedure, collection of data and analytical framework.

\section{Sampling technique}

The study was conducted in five upazilas of Munshiganj district which were: Sreenagar, Sirajdikhan, Tongibari, Munshiganj Sadar and Gazaria. A total of 52 potato farmers taking at least 10 farmers from each upazila were selected by random sampling technique. Since the study focuses on resources use efficiency in a predominantly potato growing area an attempt was made to choose respondents from those areas which had an average level of agricultural performance in their respective sub-regions.

\section{Method of data collection}

Following the conventional survey techniques, primary data on resource availability and their use, input-output levels, prices of farm production and inputs as well as some other information were collected by interviewing the farmers personally using a designed and pre-tested questionnaire in February-March, 2016.

\section{Analytical Framework}

Both fixed cost and variable cost were taken into account in calculating cost of potato cultivation. Land use cost was calculated on the basis of per year existing lease value of land. Irrespective of potato varieties, the profitability of potato production was examined on the basis of gross return, gross margin, net return and benefit cost ratio analysis. The collected data were edited, summarized, tabulated and analyzed to fulfill the objectives of the study. 


\section{Empirical model}

Different parameters of costs and return were analyzed to measure the profitability of potato cultivation on the study area. The following algebraic equation was developed to assess the costs and returns of potato production (Sujan et al., 2017).

$$
\mathrm{GR}_{\mathrm{i}}=\sum_{\mathrm{i}=1}^{\mathrm{n}} \mathrm{Q}_{\mathrm{mi}} \mathrm{P}_{\mathrm{mi}}+\sum_{\mathrm{i}=1}^{\mathrm{n}} \mathrm{Q}_{\mathrm{bi}} \mathrm{P}_{\mathrm{bi}}
$$

Where,

$$
\begin{aligned}
& \mathrm{GR}_{\mathrm{i}}=\text { Gross return from } \mathrm{i}^{\text {th }} \text { product }\left(\mathrm{Tk} \cdot \mathrm{ha}^{-1}\right) \\
& \mathrm{Q}_{\mathrm{mi}}=\text { Quantity of the } \mathrm{i}^{\text {th }} \text { main product }\left(\mathrm{Tk} . \mathrm{ha}^{-1}\right) \\
& \mathrm{P}_{\mathrm{mi}}=\text { Average price of the } \mathrm{i}^{\text {th }} \text { main product }\left(\mathrm{Tk} . \mathrm{ha}^{-1}\right) \\
& \mathrm{Q}_{\mathrm{bi}}=\text { Quantity of the } \mathrm{i}^{\text {th }} \text { by product }\left(\mathrm{kg} \mathrm{ha} \mathrm{h}^{-1}\right) \\
& \mathrm{P}_{\mathrm{bi}}=\text { Average price of the } \mathrm{i}^{\text {th }} \text { by product }\left(\mathrm{Tk} \cdot \mathrm{ha}^{-1}\right) \\
& \mathrm{i}=1,2,3, \ldots \ldots . . \mathrm{n}
\end{aligned}
$$

Net return was calculated by deducting all costs (variable and fixed) from gross return. To determine the net return of potato production the following equation was used in the present study:

$$
\pi=\mathrm{P}_{\mathrm{y}} \mathrm{Y}-\sum_{\mathrm{i}=0}^{\mathrm{n}} \mathrm{P}_{\mathrm{xi}} \mathrm{X}_{\mathrm{i}}-\mathrm{TFC}
$$

Where,

$$
\begin{aligned}
& \pi=\text { Net return }\left(\mathrm{Tk} . \mathrm{ha}^{-1}\right) \\
& \mathrm{P}_{\mathrm{y}}=\text { Per unit price of the product }\left(\mathrm{Tk} . \mathrm{kg}^{-1}\right) \\
& \mathrm{Y}=\text { Quantity of the product per }\left(\mathrm{kg} \mathrm{ha}^{-1}\right) \\
& \mathrm{P}_{\mathrm{xi}}=\text { Per unit price of } \mathrm{i}^{\text {th }} \text { inputs }(\mathrm{Tk} .) \\
& \mathrm{X}_{\mathrm{i}}=\text { Quantity of the } \mathrm{i}^{\text {th }} \text { inputs }\left(\mathrm{kg} \mathrm{ha}^{-1}\right) \\
& \text { TFC }=\text { Total fixed cost }\left(\mathrm{Tk} . \mathrm{ha}^{-1}\right) \\
& \mathrm{i}=1,2,3, \ldots \ldots . . ., \mathrm{n} \text { (number of inputs). }
\end{aligned}
$$

The Cobb-Douglas production function is used for functional analysis of the data. It is the most widely used model for fitting agricultural production data, because of its mathematical properties, ease of interpretation and computational simplicity (Heady and Dillon, 1969). It is a homogeneous function that provides a scale factor enabling one to measure the return to scale and to interpret the elasticity coefficients with relative ease. It is also relatively easy to estimate because in logarithmic form it is linear and parsimonious (Beattie and Taylor, 1985). Thus, Cobb-Douglas specification provides an adequate representation of the agricultural production 
technology. The production of potato is likely to be influenced by different factors, such as human labour, land preparation, seed, manure, chemical fertilizer, insecticide, irrigation, etc. The functional form of the Cobb- Douglas regression equation was as follows:

$$
\mathrm{Y}=\mathrm{AX}_{1}{ }^{\beta 1} \mathrm{X}_{2}{ }^{\beta 2} \text {----------------- } \mathrm{X}_{\mathrm{n}}{ }^{\beta \mathrm{n}} \mathrm{e}^{\mathrm{ui}}
$$

The production function was converted to logarithmic form so that it could be solved by Ordinary Least Square (OLS) method i.e.

$$
\mathrm{Ln} Y=\alpha+\beta_{1} \ln \mathrm{X}_{1}+\beta_{2} \ln \mathrm{X}_{2}+\ldots \ldots \ldots \ldots \ldots \ldots \ldots+\beta_{\mathrm{n}} \ln \mathrm{X}_{\mathrm{n}}+\mathrm{U}_{\mathrm{i}}
$$

The empirical production function was the following: $\mathrm{U}_{\mathrm{i}}$

$$
\ln Y=\alpha+\beta_{1} \ln X_{1}+\beta_{2} \ln X_{2}+\beta_{3} \ln X_{3}+\beta_{4} \ln X_{4}+\beta_{5} \ln X_{5}+\beta_{6} \ln X_{6}+\beta_{7} \ln X_{7}+
$$

Where, $\mathrm{Y}=$ Return $\left(\mathrm{Tk} \cdot \mathrm{ha}^{-1}\right)$;

$\mathrm{X}_{1}=$ Human Labor $\left(\mathrm{Tk} . \mathrm{ha}^{-1}\right)$;

$\mathrm{X}_{2}=$ Land preparation cost $\left(\mathrm{Tk} . \mathrm{ha}^{-1}\right)$;

$\mathrm{X}_{3}=\operatorname{Seed}\left(\mathrm{Tk} \cdot \mathrm{ha}^{-1}\right)$;

$\mathrm{X}_{4}=$ Manure $\left(\mathrm{Tk} \cdot \mathrm{ha}^{-1}\right)$;

$\mathrm{X}_{5}=$ Chemical fertilizer $\left(\mathrm{Tk} \cdot \mathrm{ha}^{-1}\right)$;

$\mathrm{X}_{6}=$ Insecticide cost $\left(\mathrm{Tk} . \mathrm{ha}^{-1}\right)$;

$\mathrm{X}_{7}=$ Irrigation cost $\left(\mathrm{Tk} \cdot \mathrm{ha}^{-1}\right)$;

$\alpha=$ Intercept;

$\beta_{1}, \beta_{2}$---- $\beta_{7}=$ Coefficients of the respective variables; and

$\mathrm{U}_{\mathrm{i}}=$ Error term.

In order to test the resource use efficiency, the ratio of marginal value product (MVP) to the marginal factor cost (MFC) for each input is computed and tested for its equality to 1 (Sujan et al., 2017).

$$
\text { i.e. } \frac{M V P}{M F C}=r
$$

Where, $r=$ Efficiency ratio;

MVP = value of change in output resulting from a unit change in variable input (Tk.);

$\mathrm{MFC}=$ price paid for the unit of variable input (Tk.);

Under this method, the decision rules are that, when;

$\mathrm{r}>1$, the level of resource use is below the optimum level, implying under utilization of resources. Increasing the rate of use of that resource will help increase productivity. 
$\mathrm{r}<1$, the level of resources use is above the optimum level, implying over utilization of resources. Reducing the rate of use of that resource will help improve productivity.

$\mathrm{r}=1$, the level of resource use is at optimum implying efficient resource utilization.

The marginal productivity of a particular resource represents the additional to gross returns in value term caused by an additional one unit of that resource, while other inputs are held constant. When the marginal physical product (MPP) is multiplied by the product price per unit, the MVP is obtained. The most reliable, perhaps the most useful estimate of MVP is obtained by taking resources $\left(\mathrm{X}_{\mathrm{i}}\right)$ as well as gross return (Y) at their geometric means (Dhawan and Bansal, 1977). Since all the variables of the regression model were measured in monetary value, the slope co-efficient of those explanatory variables in the function represented the MVPs, which are calculated by multiplying the production co-efficient of given resources with the ratio of geometric mean $(\mathrm{GM})$ of gross return to the geometric mean $(\mathrm{GM})$ of the given resources, i.e.

$$
\begin{aligned}
& \text { In } Y=\operatorname{In} \alpha+\beta_{i} \operatorname{In} X_{i} \\
& \frac{d Y}{d X_{i}}=\beta_{i} \frac{Y}{X_{i}} \\
& \text { Therefore, } \operatorname{MVP}\left(X_{i}\right)=b_{i} \frac{\bar{Y}(G M)}{\bar{X}(G M)}
\end{aligned}
$$

Where, $\bar{Y}=$ Mean value $(\mathrm{GM})$ of gross return in Tk.

$\bar{X}_{i}=$ Mean value $(\mathrm{GM})$ of different variable input in $\mathrm{Tk}$.

$\mathrm{i}=1,2, \ldots \ldots \ldots \ldots \ldots \ldots$

MFC is the price of per unit of input. If the MFCs of all the inputs expressed in terms of an additional Tk. in calculating the ratio of MVP to MFC, the denominator will always be one, and therefore, the ratio will be equal to their respective MVP.

\section{RESULTS AND DISCUSSION}

\section{Input use pattern}

The human labour used for producing potato was found to be 226 man days per hectare of which $31.86 \%$ were family supplied. The rest $68.14 \%$ labours were used on hire basis. The cost on human labor was calculated by considering different charge for male and female labour. Average wage rate of labour was about Tk. 252. Result shows that there are higher scopes of employment generation in potato cultivation. The average cost of land preparation was Tk. 10,562 per hectare. The average amount of seed and manure used on cultivation were 2,419 and 4,787 kg per hectare, respectively. The seed rate used by the farmers was $61 \%$ higher than the recommended seed rate of $1.5 \mathrm{t} \mathrm{ha}^{-1}$ (Satter et al., 2005). The chemical fertilizers like 
urea, TSP, MoP, gypsum, zink sulphate, and boric acid were used at a rate of 348 , $426,383,15,20$, and $4 \mathrm{~kg}$ per hectare. They used higher doses of urea, TSP, MoP and zink sulphate than the recommended doses (220-250, 120-150, 220-250 and 8-10 $\mathrm{kg} \mathrm{ha}^{-1}$ ) (BARI, 2005). The data tabulated on table 1 further shows that farmers used higher amount of fertilizers compared to other areas might be due to less confidence on the recommended doses of fertilizers. Earlier study on potato also found that Munshiganj's farmers used higher dose of fertilizers (Haq et al., 1995 and Haque et al., 2012).

Table 1. Input use pattern of potato cultivation in the study area

\begin{tabular}{|c|c|c|c|}
\hline S1. No. & Items & Amount & Percentage \\
\hline \multirow[t]{3}{*}{01} & Human labour (man-days/ha): & 226 & 100.00 \\
\hline & Hired labour & 154 & 68.14 \\
\hline & Family labour & 72 & 31.86 \\
\hline 02 & Land preparation cost $\left(\mathrm{Tk} . \mathrm{ha}^{-1}\right)$ : & 10,562 & - \\
\hline 03 & Seed $\left(\mathrm{kg} \mathrm{ha}^{-1}\right)$ & 2,419 & - \\
\hline 04 & Manures $\left.\left(\mathrm{kg} \mathrm{ha}^{-1}\right)\right)$ & 4,787 & - \\
\hline \multirow[t]{7}{*}{05} & Fertilizers $\left.\left(\mathrm{kg} \mathrm{ha}^{-1}\right)\right)$ : & & \\
\hline & Urea & 348 & - \\
\hline & TSP & 426 & - \\
\hline & MoP & 383 & - \\
\hline & Gypsum & 15 & - \\
\hline & Zinc Sulphate & 20 & - \\
\hline & Boric Acid & 4 & - \\
\hline
\end{tabular}

Data Sources: Author's Calculation based on field Survey, 2016.

\section{Cost of cultivation}

For determining the cost of cultivation of potato, all variable costs like human labour, land preparation, seed, manures, fertilizers, insecticides and irrigation were calculated per hectare basis. The fixed cost of potato cultivation included cost of land use and interest on operating capital. Average bank interest rate was around 10 percent. One third parts of the interest cost included as interest on operating capital for potato production due to its use for around four month only. The cost of land use was calculated on the basis of per hectare lease value of land. Per hectare lease value of land was around Tk. 45,000 per year of which a half parts were included as cost of potato production due to potato's shorter life. The total cost included fixed cost and variable cost. The cost of potato cultivation was estimated to be Tk. 2,29,900 and Tk. $2,00,075$ per hectare on total cost and variable cost basis, respectively. Detail result 
tabulated on table 2. The major share in total cost included seed cost $(36.82 \%)$, followed by human labour cost $(24.82 \%)$ and chemical fertilizers cost (11.08\%).

Haque et al. (2012) found the cost of potato cultivation in Munshigonj (Tk. 2,32,283 $\mathrm{ha}^{-1}$ ) was found higher than that of Bogra (Tk. 2,05,971 ha $\mathrm{ha}^{-1}$ ) and Comilla (Tk. $1,93,636 \mathrm{ha}^{-1}$ ) due to the higher cost of human labour, fertilizer and insecticides. They also found the seed cost as constituting the major share $(42 \%)$ of total cost followed by chemical fertilizers cost $(21 \%)$ and human labour cost $(14 \%)$ for potato production in some selected area of Bangladesh. However, cost of tuber seed is an important constraint in potato production. Islam et al. (2000) also found the tuber seed cost as 35 to 40 percent of total cost of production. Scarcity of quality seed in sowing time is the major causes for higher seed cost and government intervention on fertilizer market by providing subsidy on fertilizer is the major cause for lower fertilizer cost of potato production. On the other hand Bajracharya and Sapkota (2017) found FYM constituted highest (45.32\%) portion of the cost of production followed by seed and human labor in Baglung district of Nepal.

Table 2. Cost of production of potato in the study area

\begin{tabular}{c|l|c|c}
\hline S1. No. & \multicolumn{1}{c|}{ Items } & Amount $\left(\mathrm{Tk}^{\mathrm{ha}} \mathrm{ha}^{-1}\right)$ & Percentage of total cost \\
\hline A. & Variable Cost: & $2,00,075$ & 87.03 \\
& Land preparation cost & 10,562 & 4.60 \\
& Human labour & 57,068 & 24.82 \\
& Hired labour & 38,887 & - \\
& Family labour & 18,181 & - \\
& Seed & 84,650 & 36.82 \\
& Organic manure & 4,787 & 2.08 \\
& Chemical fertilizers: & 25,474 & 11.08 \\
& Urea & 5,571 & - \\
& TSP & 9,371 & - \\
& MoP & 5,744 & - \\
& Gypsum & 438 & - \\
& Zinc sulphate & 4,067 & - \\
& Boric Acid & 282 & 6.16 \\
& Insecticides & 14,148 & 1.47 \\
& Irrigation & 3,386 & 12.97 \\
B. & Fixed cost: & 29,825 & 10.07 \\
& Land use & 23,156 & 2.90 \\
& Interest on operating capital & 6,669 & 100.00 \\
\hline & Total Cost (A+B) & $2,29,900$ &
\end{tabular}

Data Sources: Author's Calculation based on field Survey, 2016 


\section{Profitability of potato cultivation}

The yield of potato was 29.5 tons per hectare which was higher than the national average yield (19.13 $\mathrm{t} \mathrm{ha}^{-1}$ ) (BBS, 2015). Estimated average farm gate price was Tk. 11.75 per $\mathrm{kg}$. The gross return and gross margin of potato cultivation were Tk. $3,47,200$ and Tk. 1,47,125 per hectare, respectively. The net return of potato cultivation was Tk. 1,17,300 per hectare. Although extra amount of variable inputs were used by farmer the average benefit-cost ratios (BCR) were 1.51 and 1.74 on full cost and variable cost basis. Estimated BCR implicate that the cultivation of potato was still remunerative to the farmers.

Gross margin was found to be the highest (Tk. 1,91,345) in Munshigonj district than any other potato producing area of Bangladesh by Haque et al. (2012). They also found the net return of potato cultivation was Tk. 1,62,873with the BCR of 1.70 and 1.94 on full cost and variable cost basis, respectively for the same district. Ahmed et al., (2009) also observed around Tk. 2,62,625, Tk. 1,20,221 and Tk. 1,42,403 as gross return, gross cost and net return, respectively with undiscounted benefit-cost ratio 2.18 for potato production in some selected areas of Mymensingh district. On the other hand Bajracharya and Sapkota (2017) found the productivity 9.89 ton per hectare with per hectare profit of NRs.70,861 with BCR of 1.44 from potato production in Baglung district of Nepal. Moreover, Islam et al. (2000) carried out a research on two production systems of potato TPS and traditional tuber technology and found variability in costs and returns for those two. The TPS technology was found to have a higher benefit-cost ratio than the traditional technology.

Table 3. Profitability of potato cultivation in the study area

\begin{tabular}{|c|c|c|c|c|}
\hline Sl. No. & Items & Formula & Unit & Amounts \\
\hline 01 & Yield & $Y$ & $\mathrm{~kg}$ ha-1 & 29,549 \\
\hline 02 & Farm gate Price & $P$ & Tk. $\mathrm{kg}^{-1}$ & 11.75 \\
\hline 03 & Gross return $(G R)$ & $Y^{*} P$ & Tk. ha ${ }^{-1}$ & $3,47,200$ \\
\hline 04 & Total variable cost & $T V C$ & Tk. ha ${ }^{-1}$ & $2,00,075$ \\
\hline 05 & Total cost & $T C$ & Tk. ha ${ }^{-1}$ & $2,29,900$ \\
\hline 06 & Gross margin & $G R-T V C$ & Tk. ha ${ }^{-1}$ & $1,47,125$ \\
\hline 07 & Net return & $G R-T C$ & Tk. ha ${ }^{-1}$ & $1,17,300$ \\
\hline \multirow[t]{3}{*}{08} & Benefit cost ratio & & & \\
\hline & Full cost basis & $G R / T C$ & & 1.51 \\
\hline & Variable cost basis & $G R / T V C$ & & 1.74 \\
\hline
\end{tabular}

Data Sources: Author's Calculation based on field Survey, 2016 


\section{Factors affecting gross return of potato}

In order to assess the contribution of inputs like human labour, land preparation, seed, manure, chemical fertilizers, insecticide and irrigation for potato production, Cobb-Douglas production function model was used. The estimated values of coefficient and related statistics of Cobb-Douglas production function have been presented in table-4. All the co-efficients of human labour, fertilizer and irrigation were positive and significant at $1 \%$ level. The co-efficient of seed and insecticide application were positive and significant at 5\% level. The co-efficient of land preparation was positive and significant at $10 \%$ level. Manure application had positive impact on the yield of potato but the effects were not significant at desired level of significance. The study revealed that an increase in $10 \%$ cost of human labor, land Preparation, seed, fertilizer, insecticide and irrigation, remaining other factors constant would increase the gross return of potato by $1.84,0.37,0.79,1.75,0.72$ and $0.27 \%$, respectively.

The value of the co-efficient of multiple determination $\left(\mathrm{R}^{2}\right)$ of the model was 0.77 indicating about 77 percent of the variation in gross return of potato production were explained by the explanatory variables included in the model.

Table 4. Estimated coefficients and their related statistics of production function for potato

\begin{tabular}{lcccc|c|c}
\hline Explanatory Variable & Parameters & Co-efficient & Sd. Error & t-values & P-values \\
\hline Intercept & $\beta_{0}$ & $6.733^{* * *}$ & 0.777 & 8.664 & 0.000 \\
Human labor $\left(X_{1}\right)$ & $\beta_{1}$ & $0.184^{* * *}$ & 0.061 & 3.015 & 0.004 \\
Land Preparation $\left(X_{2}\right)$ & $\beta_{2}$ & $0.037^{*}$ & 0.020 & 1.840 & 0.072 \\
Seed $\left(X_{3}\right)$ & $\beta_{3}$ & $0.079^{* *}$ & 0.032 & 2.500 & 0.016 \\
Manure $\left(X_{4}\right)$ & $\beta_{4}$ & $0.011^{\text {NS }}$ & 0.023 & 0.494 & 0.624 \\
Fertilizer $\left(X_{5}\right)$ & $\beta_{5}$ & $0.175^{* * *}$ & 0.059 & 2.966 & 0.005 \\
Insecticide $\left(X_{6}\right)$ & $\beta_{6}$ & $0.072^{* *}$ & 0.031 & 2.317 & 0.025 \\
Irrigation $\left(X_{7}\right)$ & $\beta_{7}$ & $0.027^{* * *}$ & 0.010 & 2.773 & 0.008 \\
$\mathrm{R}^{2}$ & & 0.77 & & & \\
F-value & \multicolumn{7}{c}{$26.08^{* * *}$} \\
Return to scale & & 0.59 & & \\
\hline
\end{tabular}

Note: $* * *, * *$ and $*$ indicate significant at $1 \%, 5 \%$ and $10 \%$ level, respectively.

Data Sources: Author's Calculation based on field Survey, 2016

The measure of the overall fit of the estimated regression, F-value (26.08) was significant at 1 percent level of significance, implying that all the explanatory variables included in the model were important for explaining the variations in gross returns of potato production. 
Haque et al. (2012) also found all the co-efficients of human labour, land preparation, seed and NPK fertilizer were positive and significant at $1 \%$ level of significance indicating $10 \%$ increase in the cost of human labor, land preparation, seed and NPK fertilizer, remaining other factors constant would increase the yield of potato by 2.25 , $0.76,3.13$ and $3.86 \%$, respectively. Ahmed et al. (2009) also carried out a research on the same and the research revealed that seed and pesticides had positive but TSP and MP had negative significant effect on gross return of potato production in Mymensing district of Bangladesh. Bajracharya and Sapkota (2017) also found human labor, seed, FYM, cost of bullock labor and intercultural operation having significant effect on total income of potato in Baglung district of Nepal where an increase in $1 \%$ cost of human labor, seed and FYM would increase the total income of potato by $0.075 \%, 0.639 \%$ and $0.190 \%$, whereas $1 \%$ increase in the cost of bullock labor and intercultural operation would decrease income by $0.015 \%$ and $0.047 \%$, respectively.

\section{Return to scale}

The summation of all the production co-efficient $\left(\beta_{\mathrm{i}}\right)$ indicates the return to scale. The return to scale of potato cultivation in Munshiganj district was found around 0.59 which indicate the diminishing return to scale. It means potato farmers allocated their resources in the rational stage of production (Stage-II) where lower amount of return would be added to the gross return by using each additional units of input to the potato cultivation.

The return to scale of potato cultivation in Munshiganj, Bogra and Comilla district of Bangladesh was found 0.965 by Haque et al. (2012) which was 0.218 for Mymensing district of Bangladesh found by Ahmed et al. (2009). Islam et al. (2000) carried out a research on the same topic in Bangladesh and found from efficiency analysis that the potato growers using TPS technology allocated their resources in rational stage of production. Later, Bajracharya and Sapkota (2017) also found the return to scale of potato cultivation 0.842 in Baglung district of Nepal.

\section{Resource use efficiency}

Resource use efficiency means how efficiently the farmer can use his resources in the production process. It is very important because resource is scarce. For calculating resource use efficiency, the study considered seven input factors namely human labor, land preparation, seed, manure, fertilizer, insecticide and irrigation. 
Table 5. Resource use efficiency of different inputs under potato cultivation

\begin{tabular}{c|c|c|c|c|c|c}
\hline Variable & $\begin{array}{c}\text { Geometric } \\
\text { mean }(\mathrm{GM})\end{array}$ & $\begin{array}{c}\overline{\mathrm{Y}}(\mathrm{GM}) / \\
\overline{\mathrm{X}}_{\mathrm{i}}(\mathrm{GM})\end{array}$ & $\begin{array}{c}\text { Co- } \\
\text { efficient }\end{array}$ & $\begin{array}{c}\text { MVP }\left(\mathrm{X}_{\mathrm{i}}\right. \\
)\end{array}$ & $\begin{array}{c}\mathrm{r}=\mathrm{MVP} / \\
\mathrm{MFC}\end{array}$ & Decision rule \\
\hline $\begin{array}{c}\text { Yield }(Y) \\
346751.9\end{array}$ & & & & & \\
$\begin{array}{c}\text { Human labor } \\
\left(X_{1}\right)\end{array}$ & 56918.64 & 6.092 & 0.184 & 1.121 & 1.121 & Under-utilization \\
$\quad \begin{array}{c}\text { Land } \\
\text { Preparation }\left(X_{2}\right)\end{array}$ & 10364.93 & 33.454 & 0.037 & 1.238 & 1.238 & Under-utilization \\
$\quad$ Seed $\left(X_{3}\right)$ & 84014.31 & 4.127 & 0.079 & 0.326 & 0.326 & Over-utilization \\
Manure $\left(X_{4}\right)$ & 4731.044 & 73.293 & 0.011 & 0.806 & 0.806 & Over-utilization \\
Fertilizer $\left(X_{5}\right)$ & 25390.58 & 13.657 & 0.175 & 2.390 & 2.390 & Under-utilization \\
Insecticide $\left(X_{6}\right)$ & 14034.89 & 24.706 & 0.072 & 1.779 & 1.779 & Under-utilization \\
Irrigation $\left(X_{7}\right)$ & 3053.159 & 113.572 & 0.027 & 3.066 & 3.066 & Under-utilization \\
\hline
\end{tabular}

Note: MFC=1TK. Data Sources: Author's Calculation based on field Survey, 2016

From table-5, it is observed that the ratio of marginal value products (MVP) and marginal factor cost (MFC) for human labour, land preparation, fertilizers, insecticide and irrigation were greater than unity indicating the under-utilization of those resources. Which means increasing the rate of use of those resources would help to increase the productivity. Same ratio for seed and manure were less than unity indicating over-utilization of those variables. Which means reduction of the rate of use of those resources would help to improve the productivity. Islam et al. (2000) conducted a research on potato production system in Bangladesh and found inefficiency in the uses of human labour, seed, manure and fertilizers in TPS technology, which had a potentiality to increase potato output by 20 percent with efficient organization of those resources.

\section{CONCLUSION}

It is evidenced from the study that cultivation of potato in Munshiganj district of Bangladesh is a profitable venture. Each taka invested in potato cultivation would return 1.51 taka to its investor. Seed cost was found as the major cost (36.82) constituents of total cost. Besides, over doses chemical fertilizer applied for potato cultivation but their effects on yield were still remunerative. Nevertheless, farmers allocated their resources in the rational stage (Stage-II) of production where diminishing returns to scale (0.59) existed. Sufficient supply of quality seed at fair price in sowing time can help to reduce the cost of production. Furthermore, optimum use of fertilizer can also increase the productivity and profitability of potato cultivation. 


\section{REFERENCES}

Akhter, S.M.M., Anwar and Asaduzzaman, M. (2001). Potato production in some selected areas of Bangladesh. TCRC. BARI, Joydebpur, Gazipur, Bangladesh.

Akhter, M.E.M.S., Ali, Z.N., Huq, A.K.M.A., Habib, M.A., and Hossain, A.B.S. (1998). Granula, Cleopatra and Binella New Potato Varieties in Bangladesh, Progressive Science, 24(1), 133-143.

Ahmed, S., Rashid, M.H.A., and Chowdhury, N. (2009). Comparative profitability of boro rice and potato production in some selected areas of Mymensingh district. Progressive Agriculture, 20(1 \&2), 253-258. doi: http://dx.doi.org/10.3329/pa.v20i1-2.16880.

Azimuddin, M., Alam, Q.M., and Baset, M.A. (2009). Potato for food security in Bangladesh. International Journal of Sustainable Crop Production, 4(1), 94-99.

Bajracharya, M., and Sapkota, M. (2017). Profitability and productivity of potato (Solanum tuberosum) in Baglung district, Nepal. Agriculture \& Food Security, 6, 47. doi: https://doi.org/10.1186/s40066-017-0125-5

BARC, (Bangladesh Agricultural Research Council). (2005). Fertilizer Recommendation Guide, Published by the Bangladesh Agricultural Research Council, Farmgate, Dhaka1215.

BARI, (Bangladesh Agricultural Research Institute). (2005). Handbook of Agricultural Technology $3^{\text {rd }}$ edition, Gazipur.

BBS, (Bangladesh Bureau of Statistics). (2015). Year book of Agricultural Statistics of Bangladesh, Statistics Division, Ministry of Planning, Government of the People's Republic of Bangladesh, Dhaka, Bangladesh.

Beattie, B.R., and Taylor, C.R. (1985). The Economics of Production. Montana State University, John Wiley and Sons, New York, USA.

Dhawan K.C., and Bansal, P.K. (1977). Rationality of the Use of Various Factors of Production on Different Sizes of Farm in the Punjab, Indian Journal of Agricultural Economics, 32(3), 121-130.

Elias, S.M., Miah, M.R.U., Hossain, M.J., Torofder, G.S., and Islam, M.S. (1992). Effect of potassium on the growth and yield of potato. Bangladesh Journal of Agricultural Research, 17(7), 91-93.

FAOSTAT. (2015). (United Nations Food and Agriculture Organization) (Production/ Core Production Data).

Haque, M.A., Miah, M.A.M., Hossain, S., and Rahman, M.M. (2012). Profitability of BARI released potato (Solanum tuberosum L.) varieties in some selected locations of Bangladesh. Bangladesh Journal of Agricultural Research, 37(1), 149-158.

Heady, E.O., and Dillon, J.L. (1969). Agricultural Production Functions. Iowa State University Press, Ames.

Hoq, A.S.M.A. (1998). Comparative profitability of potato under different situation in Dinajpur. Bangladesh Journal of Agricultural Research, 23(1). 
Huq, A.S.M.A., Hussain, M.S., and Rashid, M.A. (1995). Potato production in CDP demonstration area: Yield gap analysis. Annual report, Agricultural Ecinomics Division, BARI, Gazipur.

Islam, S.M.F., Anwar, M.M., and Manos, B. (2000). Potato production system in Bangladesh: Resource use, productivity, efficiency and comparative profitability of true potato seed technology over traditional tuber technology. Acta Hortic, 536, 261-268 doi: 10.17660/ActaHortic.2000.536.30.

Islam F., and Sujan M.H.K. 2016. Rationality of hog plum cultivation in Jhalokathi district, an empirical analysis in the socio-economic context of Bangladesh. Journal of Advances in Social Science and Humanities, 2(1), 8-18. doi: http://dx.doi.org/10.15520/2126.

Khalil, M.I., Haque, M.E., and Hoque, M.Z. (2013). Adoption of BARI recommended potato (Solanum tuberosum) varieties by the potato farmers of Bangladesh. The Agriculturists, 11(2), 79-86, doi: http://dx.doi.org/10.3329/agric.v11i2.17492.

Miah, M.A.M., Hossain, S.T.M.B., and Rahman, S. (2011). Assessment of potato farmers' perceptions on abiotic stresses and implications for potato improvement research in Bangladesh: A baseline survey. Research report submitted to International Potato Centre (CIP), Lima, Peru.

Moniruzzaman., Hoq, M.S., Islam, M.K., Jasmin, J., and Khanam, M.M. (2015). Agroeconomic performance of seed potato production under contract farming in Bangladesh. Eco-friendly Agricultural Journal, 8(3), 30-36.

Rahman, K.M.M. (2002). Measuring efficiency of producing rice in Bangladesh: A stochastic frontier analysis. Unpublished [Ph.D Thesis], Institute of Agricultural Policy and Marketing Research, Justus-Liebig University, Giessen, Germany.

Sarkar, M.M.A., and Yesmin, F. (2014). Profitability of potato cultivation in some selected areas of Rangpur district in Bangladesh. International Journal of Sustainable Crop Production, 9(1), 11-15.

Satter, M.A., Rahman, M.M., Rashid, M.H., Ali, M.S., and Alam, M.S. (2005). Krishi Projukti Hatboi (Hand book on agro technology), $3^{\text {rd }}$ ed, BARI, Gazipur.

Sujan, M.H.K., Islam F., Azad M.J., and Rayhan, S.J. (2017). Financial profitability and resource use efficiency of boro rice cultivation in some selected area of Bangladesh. African Journal of Agricultural. Research. 12(29), 2404-2411. doi: 10.5897/AJAR2017.12443.

Walker, T.S., Schmiediche., P.E., and Hijmans, R.J. (1999). World trends and patterns in the potato crop: An economic and geographic survey. Potato Research, 42(2), 241-264.

Yadav, S.K., Srivastava, A.K., Bag, T.K., Kumar, Y., and Kumar, K. (2015). Productivity, profitability and resource use efficiency of potato (Solanum tuberosum) based cropping systems in eastern Himalayan region. Indian Journal of Agricultural Sciences, 85 (7), 921-5. 